Розділ І. Ціннісні орієнтири духовно-інтелектуального виховання, розвиток духовно-інтелектуальних якостей особистості в умовах співпраці й інклюзії

\title{
ДО ПРОБЛЕМ ОРГАНІЗАЦІЇ ОСВІТНЬОГО ПРОЦЕСУ НА УРОЦІ ХОРЕОГРАФІЇ
}

\author{
Алтухов В. А. \\ кандидат педагогічних наук, доцент, Харківський національний \\ педагогічний університет імені Г.С. Сковороди, м. Харків, Україна
}

У статті розглядаються проблеми організації освітнього процесу і розвитку художньо-творчих здібностей школярів засобами хореографічного мистецтва. Розкрито поняття иілісності педагогічного процесу на уроиі хореографії. Показані різні варіанти ведення уроків хореографії. Надані деякі рекомендації молодим викладачам хореографії.

Ключові слова: хореографія, освіта, урок, вчитель.

This article discusses the problems of organization of educational process and development of artistic and creative abilities of students by means of choreography. The concept of the integrity of the pedagogical process in the lesson of choreography is revealed. Different options for conducting choreography lessons are shown. Some recommendations are given to young teachers of choreography.

Key words: choreography, education, lesson, teacher.

Розмірковуючи над проблемами організації освітнього процесу на уроці хореографії, ми не можемо не звернути уваги на те, що на кожному уроці присутня і цілісність, і логічна завершеність, і обмеженість тимчасовими рамками, і план роботи, і кількість учасників. Урок - це, безперечно, показник: роботи вчителя та учнів. Якщо мова йде про звичні зовнішні (формальні) ознаки цієї роботи, то тут ніяких проблем немає: особливих складнощів для будь-якого вчителя не буде, щоб продемонструвати всі зовнішні показники успішності своєї діяльності: і логіку, і чіткість, і організованість, і відповідність заняття плану.

Ми ж дотримуємося дещо іншої думки про урок, представляючи його в якості головної форми організації навчального процесу: форма, яка представлена в сучасній педагогіці як зовнішній вигляд, зовнішнє окреслення. Таке розуміння форми знімає необхідність звертатися до того, як вважає С. В. Кульневич, «...що поняття форми в першу чергу залежить від того, що вона оформляє, чому вона надає певний вид. Ці «що» і «чому» - зміст, форма — це те, що виражає зміст. Причому не тільки структурний зміст уроку — організаційний момент, поста- 
новку мети, опитування, завдання тощо, але й те, на чому все це стоїть, з чого виникає, які цінності для особистості, що розвивається. Тому мова повинна вестися про цілісність уроку, як єдності його форми та змісту» [2, с. 26].

Погоджуючись $з$ автором, ми встаємо на позицію того, що в сучасній педагогіці урок не є умовою реалізації цілісності освітнього процесу. Однак необхідно звернутися до специфіки даного дослідження і виявити особливості хореографічного уроку, який в силу своєї художності, не завжди відповідає тенденціям і положенням загальної дидактики.

Поява концепції В. М. Нілова про хореографічну освіту й заснованих на ній програми та методичного посібника стало помітним явищем в педагогічному житті. Таким чином, В. М. Нілов вивів систему хореографічної освіти на новий рівень мислення, де культура мислення формується в процесі пізнання шкільного «предмета», який сам $\epsilon$ сховищем духовності, «всього найкращого, що передумало, та пережило людство», і при цьому розглядає життя і мистецтво у філософському аспекті. Тому немає іншого шляху, окрім як перевести викладання хореографічного мистецтва на філософський рівень [3, с. 73].

Розглянемо приклади того, як на практиці сучасними вчителями хореографії здійснюється процес викладання і якого рівня мислення розвивають вони в учнях на своїх уроках. Перше, що доводиться відзначити, це примітивізація змісту хореографічного мистецтва в загальноосвітній школі. На жаль, багато хто вважає, що урок хореографії в школі повинен мати характер радісного дійства, де учні можуть якщо не відпочивати, то виходити з уроку лише з позитивними враженнями.

Іншу варіацію на тему «урок хореографії» пропонують сьогодні педагоги - так звані послідовники системи елементарного розвитку творчих здібностей школярів. Урок хореографії наповнюється різними пластичними рухами, що визначають настрій музики та засоби виразності, він сповнений творчими ритмічними імпровізаціями тощо.

Ще один момент, на який страждає сучасна хореографічна освіта, - зайва затеоретизованість. Подібне теоретизування на уроках хореографії у загальноосвітній школі слід обмежувати «почуттям міри у викладі фактів, цифр, цитат» [4, с. 69].

Наступною крайністю все тієї ж зайвої теоретизації є той факт, що уроки хореографії в школі відрізняються насиченою інформацією, 
Розділ І. Ціннісні орієнтири духовно-інтелектуального виховання, розвиток духовно-інтелектуальних якостей особистості в умовах співпраці й інклюзії

високим темпом роботи, підвищеною інтенсивністю навчально-пізнавальної діяльності учнів, різнобічністю видів творчої діяльності.

Таким чином, урок хореографії зводиться до простого виконання рухів, до суми видів діяльності та організаційних перестановок. І якщо на кожному такому уроці, знайомлячись 3 новим хореографічним твором, учні й будуть говорити про зміст, форми, фактури, засоби виразності, то це все ще залишиться просто термінологічно оформленою констатацією знань. А оскільки така розумова діяльність йде поза єдності зі змістом, а також поза єдності приватних проявів у контексті загального цілого - художньої ідеї твору, то подібна практика якщо й не шкодить, то точно не розвиває мислення учня.

Так, Н. І. Тарасов в розділі «Школа», дає рекомендації молодим викладачам хореографам, з чого починається та як проходить процес формування, створення уроку хореографії, центральним моментом якого є реалізація «творчого задуму», ідеї уроку. Що ж автор має на увазі під задумом уроку хореографіï?

«Розробляючи урок хореографії, - пише Н. I. Тарасов - треба пам'ятати, що їхня ідея може залежати не тільки від програми та педагогічного завдання, що стоїть перед учителем, а й від часу, коли рекомендована програма освоюється» [4, с. 17].

Слідом за загальнотеоретичним та практичним оглядом того, що відбувається в хореографічному навчанні хотілося б розглянути деякі програми $з$ хореографії, рекомендовані Міністерством освіти, варіативність використання яких також явище неоднозначне, тому що принципово різні розуміння результату хореографічного навчання, відсутність єдиної стратегії в розвитку художнього мислення учнів, 3 одного боку, та у зв'язку з цим відсутність єдиної методології та єдності формується мислення у майбутніх педагогів-хореографів, з іншого боку, - ось лише деякі, але досить суттєві недоліки ситуації, що склалися.

Безсумнівним плюсом програм є трактування уроку хореографіï «як уроку мистецтва, морально-естетичним стрижнем якого є художньо-педагогічна ідея ...вічні теми мистецтва: добро і зло, любов і ненависть, життя і смерть, материнство, захист Вітчизни тощо» [1, с.87].

Спираючись на аналіз педагогічної та методичної літератури, який був зроблений В. М. Ніловим у галузі мистецької освіти та виховання 
школярів засобами хореографічного мистецтва, можна виділити три основні напрямки:

- перший - художнє виховання розвивається та функціонує на базі поза шкільних установ культури - клубів, Будинків і Палаців культури.

- другий напрямок мистецької освіти розвивається на базі хореографічних відділень (освітнього рівня) Дитячих музичних шкіл (ДМШ) і Дитячих шкіл мистецтв (ДШМ), а також окремих самостійних Дитячих хореографічних та балетних шкіл (ДХШ).

- третій напрямок художнього виховання засобами хореографічного мистецтва в умовах загальноосвітньої школи є - позакласна робота або факультативна за бажанням (для цього в програмі школи закладено години для різних гуртків самодіяльної творчості) [3, с. 80].

Аналізуючи педагогічну ситуацію в сучасній школі, можна відзначити, що в останні роки спостерігається тенденція до розширення використання хореографічного мистецтва в загальноосвітніх школах. Виникла не тільки потреба в систематичній цілеспрямованій хореографічній освіті на базі загальноосвітніх шкіл при взаємодії з установами культури, але намітилися тенденції формування та розвитку нової структури хореографічного напрямку освіти в навчально-виховному процесі загальноосвітньої школи.

Провівши даний екскурс по сучасному хореографічному освітньому простору, ми можемо зробити висновок, що:

- високий рівень технократизму та дидактизму, присутній у багатьох педагогічних системах, концепціях й працях, демонструє відсутність теоретичного мислення та діалектичної логіки в їх основі;

- поняття цілісності педагогічного процесу на уроці хореографії береться лише в вузько формальному сенсі слова, а наукові підходи, на які посилаються сучасні автори, мають, по суті, одностороннє та поверхневе осмислення;

- проблема творчого розвитку учня на уроці хореографії нині не вирішена системно, в цілісності всіх елементів й рушійних сил даного процесу. 
Розділ І. Ціннісні орієнтири духовно-інтелектуального виховання, розвиток духовно-інтелектуальних якостей особистості в умовах співпраці й інклюзії

\section{Список використаних джерел:}

1. Биковська Т. В., Шкура Г. А. Навчальні програми з позашкільної освіти художньо-естетичного напряму. Київ : УДЦПО, 2016. Вип. 1. С. 87.

2. Кульневич, С. В. Современный урок: [научно-практич. пособие для учителей, методистов, руководителей учебных заведений, студентов пед. учеб. заведений, слушателей ИПК]. Ростов-на-Дону : Учитель, 2004. Часть I.

3. Нилов В. Н. Современное состояние хореографического искусства в художественном образовании детей и молодежи. Москва, 2010. С. 73-82.

4. Тарасов, Н. И. Классический танец. Школа мужского исполнительства. Москва : Искусство, 1971. 492с. 